\title{
オブザーバを用いた適応ゲインコントローラによる 未知パラメータを含む線形システムに対するロバスト制御†
}

\author{
松 岡 正 喜*·萩 野 剛二郎**
}

\author{
Robust Control for a Linear System with Uncertainties \\ via an Adaptive Gain Controller Using an Observer $^{\dagger}$ \\ Masaki MatsuokA* and Kojiro HaGino**
}

\begin{abstract}
In this paper, we propose a design method of an adaptive gain controller using an observer for a linear timeinvariant system with uncertainties in the system matrix and the input matrix. The proposed controller consists of a fixed gain part and an adaptive gain part related to estimated values and inputs. In the case that uncertainties in the system matrix and the input matrix satisfy the matching conditions, we need no information on the upper bound of matched uncertainties for the design process. Finally, the effectiveness of the proposed controller is demonstrated by numerical simulations.
\end{abstract}

Key Words: adaptive gain controller, observer, matching condition, robust control

\section{1.はじめに}

モデル化誤差やパラメータ摂動による不確かさを含む線形 システムに対するロバスト制御に関する研究は広く行なわれ ている。一般に実際のシステムにおいては，物理的，技術 的, 経済的な面から, 状態のすべては知ることができない場 合が多く, 制御系設計においては出力フィードバック制御か オブザーバ併用の制御系を設計する必要がある。しかしなが ら, 出力フィードバックによる制御系設計は, システムに不 確かさが存在しない場合でもフィードバックゲインを決定す ることが難しい場合が多く ${ }^{14)}$, 不確かさが存在する場合にお いてはさらに制約が厳しくなり，安定化条件を満足する制御 則を得ることが難しくなる ${ }^{11), 13)}$. 一方, 状態がすべて観測 できる場合の状態フィードバックによる設計法も多く提案さ れ2) 4),6)，またオブザーバを用いた制御系設計法も，同次 元オブザーバを用いた場合 7) 11)や低次元オブザーバを用い た場合 ${ }^{12)}$ に対する安定化コントローラの設計法が提案され ている. しかしながら提案されている設計法は, 不確かさの 上界が既知であるという仮定の下で，安定化のための設計パ

$\dagger$ 第 44 回自動制御連合講演会で発表 $(2001 \cdot 11)$

*. 湘南工科大学 藤沢市辻堂西海岸 1-1-25

** 電気通信大学 調布市調布ヶ 丘 1-5-1

* Shonan Institute of Technology, 1-1-25 Tsujidounishikaigan, Fujisawa

** University of Electro-Communications, 1-5-1 Chofugaoka, Chofu

(Received October 24, 2001)

(Revised March 8, 2002)
ラメータを調整しながら安定化条件として導出されたリカッ チ方程式やリアプノフ方程式を解くことによりコントローラ を設計するタイプのものが多い. 数值探索法等により効率的 に求める方法も提案されているが，場合によっては安定化制 御則が得られない場合が生じる。また，動作環境の変化によ り, 不確かさの上界が変化した場合には, 設計パラメータの 調整を再度行ない, 制御系の再構築を行なう必要が生じる.

一方, ASPR 化可能なシステムに対し可変ゲインコント ローラを用いた適応制御の研究もされている ${ }^{5)}$. また, Choi ${ }^{6)}$ らはロボットマニピュレータに対するシステムの線形化誤差 等の不確かさを考慮した適応ゲイン状態フィードバックコン トローラを提案している。この制御則は状態がすべて観測で きる場合に対し，規範モデルに対する固定ゲイン状態フィー ドバックコントローラと摂動パラメータを考慮した適応的可 変ゲインコントローラで構成されており, システムの漸近安 定性をリアプノフの直接法を用いて示している.

本論文では, Choi らの適応制御則にそって, 不確かさを 含む線形時不変システムにおいて状態のすべては観測でき ない場合に対し，オブザーバを用いた適応ゲイン出カフィー ドバックコントローラの設計法を提案する. 提案するコント ローラは, オブザーバから得られた推定值をフィードバック する固定ゲインコントローラとオブザーバから得られた推定 值を反映した可変ゲイン出カフィードバックコントローラで 構成される. システムの安定性は, オブザーバベースのリア プノフ関数を用いて示す. 提案するコントローラは, システ ムに対する可制御, 可観測, 可検出性の仮定を満たすシステ 
ムであれば，それぞれの不確かさがマッチング条件を満たす ときには，不確かさに対する上界の情報を必要としないとい う特徵をもち, リカッチ方程式によるロバスト制御系設計法 で必要であるパラメー夕調整を必要としない。また，不確か さを含むシステム行列 $A+\Delta A$ に対して観測行列 $C$ との可 検出性を仮定し，それぞ机の不確かさに対してマッチング条 件を仮定しているため対象とするシステムに対する条件が厳 しくなっている部分もあるが，その条件さえ満たせば確実に システムの安定性を保証するコントローラを得ることができ るという点で有効な設計法である.

本論ではシステム行列と駆動行列両方に不確かさが存在す る時を考え，第 2 章で問題の定式化を行ない，第 3 章で安定 化制御則の導出を行なう. 第 4 章では簡単な数值例を通して その有効性を示し，第 5 章で本論文のまとめを行なう.

\section{2. 問題の定式化}

つぎのシステム行列と駆動行列に不確かさを含む時不変線 形システムを考える.

$$
\left\{\begin{array}{l}
\dot{\boldsymbol{x}}=(A+\Delta A) \boldsymbol{x}+(B+\Delta B) \boldsymbol{u} \\
\boldsymbol{y}=C \boldsymbol{x}
\end{array}\right.
$$

ここで $\boldsymbol{x} \in \Re^{n}, \boldsymbol{u} \in \Re^{m}, \boldsymbol{y} \in \Re^{l}$ は状態, 入力, 出力べ クトルを表わし, $A, B, C$ は適当な次元のシステム行列, 駆動行列, 観測行列で, $B$ はフルランクとし, また $(A, B)$, $(A, C)$ は可制御，可観測ペアとする。ここで $A$ は安定行列 とし，Aが安定でない場合には Kucera ${ }^{14)}$ の方法等を用いて 出力フィードバックにより安定化しておく. $\Delta A, \Delta B$ はシ ステム行列と駆動行列の不確かさを表わす行列でつぎのマッ チング条件を満たすものとする.

$$
\Delta A=B L^{*} C, \quad \Delta B=B M^{*}
$$

ここで $L^{*}, M^{*}$ は未知であるが, $(A+\Delta A, C)$ は $\Delta A$ の変 動範囲内で可検出であるとする。 入力として次式を考える.

$$
\boldsymbol{u}=-K \hat{\boldsymbol{x}}-L \boldsymbol{y}-M \boldsymbol{u}
$$

$K$ は不確かさを無視したノミナルシステムに対する LQ 最 適ゲインで

$$
K=R^{-1} B^{T} P
$$

とし，Pはつぎのリカッチ方程式の対称正定解である.

$$
A^{T} P+P A-P B R^{-1} B^{T} P+Q=0
$$

ただし $Q=Q^{T}>0, R=R^{T}>0$ とし $, L, M$ は後で決 める行列である，(2) 式，(3) 式を (1) 式に代入すると

$$
\begin{aligned}
\dot{\boldsymbol{x}}= & \left(A+B L^{*} C\right) \boldsymbol{x}-B K \hat{\boldsymbol{x}}-B L C \boldsymbol{x} \\
& -B M \boldsymbol{u}+B M^{*} \boldsymbol{u} \\
= & A \boldsymbol{x}-B\left(L-L^{*}\right) C \boldsymbol{x}-B K \hat{\boldsymbol{x}}-B\left(M-M^{*}\right) \boldsymbol{u} \\
= & A \boldsymbol{x}-B \Delta L C \boldsymbol{x}-B K \hat{\boldsymbol{x}}-B \Delta M \boldsymbol{u}
\end{aligned}
$$

となる．ここで，

$$
\Delta L=L-L^{*}, \quad \Delta M=M-M^{*}
$$

である。また (3) 式の $\hat{\boldsymbol{x}}$ は $\boldsymbol{x}$ の推定值でつぎのカルマン形 オブザーバで与える.

$$
\begin{aligned}
\dot{\hat{\boldsymbol{x}}}=A \hat{\boldsymbol{x}}-B \Delta L C \hat{\boldsymbol{x}}-B K \hat{\boldsymbol{x}} & \\
& -B \Delta M \boldsymbol{u}+G(\boldsymbol{y}-C \hat{\boldsymbol{x}})
\end{aligned}
$$

そこで問題は，(6) 式のシステムが (8) 式のオブザーバを用 いた (3) 式の制御則により安定となるための行列 $L, M$ お よび (8) 式の行列 $\Delta L, \Delta M$ とオブザーバゲイン $G$ を決定 することである。

\section{3. 安定化制御則の導出}

(5) 式の解 $P$ を用いてつぎのリアプノフ関数の候補 $V$ を 考える.

$$
\begin{aligned}
V=\hat{\boldsymbol{x}}^{T} P \hat{\boldsymbol{x}} & +\operatorname{tr}\left\{\Delta L^{T} \Gamma_{1} \Delta L\right\} \\
& +\operatorname{tr}\left\{G^{T} \Gamma_{2} G\right\}+\operatorname{tr}\left\{\Delta M^{T} \Gamma_{3} \Delta M\right\}
\end{aligned}
$$

ここで $\operatorname{tr}\{\cdot\}$ は行列のトレースを表わす. (9) 式の両辺を (8) 式の解軌道に沿って時間微分し整理すると

$$
\begin{aligned}
\dot{V}= & \dot{\hat{\boldsymbol{x}}}^{T} P \hat{\boldsymbol{x}}+\hat{\boldsymbol{x}}^{T} P \dot{\hat{\boldsymbol{x}}} \\
& +\operatorname{tr}\left\{\Delta \dot{L}^{T} \Gamma_{1} \Delta L\right\}+\operatorname{tr}\left\{\Delta L^{T} \Gamma_{1} \Delta \dot{L}\right\} \\
& +\operatorname{tr}\left\{\dot{G}^{T} \Gamma_{2} G\right\}+\operatorname{tr}\left\{G^{T} \Gamma_{2} \dot{G}\right\} \\
& +\operatorname{tr}\left\{\Delta \dot{M}^{T} \Gamma_{3} \Delta M\right\}+\operatorname{tr}\left\{\Delta M^{T} \Gamma_{3} \Delta \dot{M}\right\} \\
= & \hat{\boldsymbol{x}}^{T}(A-B K)^{T} P \hat{\boldsymbol{x}}+\hat{\boldsymbol{x}}^{T} P(A-B K) \hat{\boldsymbol{x}} \\
& -\hat{\boldsymbol{x}}^{T} C^{T} \Delta L^{T} B^{T} P \hat{\boldsymbol{x}}-\hat{\boldsymbol{x}}^{T} P B \Delta L C \hat{\boldsymbol{x}} \\
& +e_{y}^{T} G^{T} P \hat{\boldsymbol{x}}+\hat{\boldsymbol{x}}^{T} P G \boldsymbol{e}_{y} \\
& -\boldsymbol{u}^{T} \Delta M^{T} B^{T} P \hat{\boldsymbol{x}}-\hat{\boldsymbol{x}} P B \Delta M \boldsymbol{u} \\
& +\operatorname{tr}\left\{\Delta \dot{L}^{T} \Gamma_{1} \Delta L\right\}+\operatorname{tr}\left\{\Delta L^{T} \Gamma_{1} \Delta \dot{L}\right\} \\
& +\operatorname{tr}\left\{\dot{G}^{T} \Gamma_{2} G\right\}+\operatorname{tr}\left\{G^{T} \Gamma_{2} \dot{G}\right\} \\
& +\operatorname{tr}\left\{\Delta \dot{M}^{T} \Gamma_{3} \Delta M\right\}+\operatorname{tr}\left\{\Delta M^{T} \Gamma_{3} \Delta \dot{M}\right\}
\end{aligned}
$$

ただし $e_{y}=C x-C \hat{\boldsymbol{x}}$ とする. ある行列 $C$ とべクトル $z$ に 関するトレースの関係 $\operatorname{tr} C \boldsymbol{z} \boldsymbol{z}^{T}=\boldsymbol{z}^{T} C \boldsymbol{z}$ が成り立つことを 用い, $-\hat{\boldsymbol{x}}^{T} P B \Delta L C \hat{\boldsymbol{x}}+\operatorname{tr}\left\{\Delta \dot{L}^{T} \Gamma_{1} \Delta L\right\}$ が相殺され，また システムの安定性を示すために必要な項が残るように $\Delta L$ を

$$
\Delta \dot{L}=\Gamma_{1}^{-1}\left(B^{T} P \hat{\boldsymbol{x}}(C \hat{\boldsymbol{x}})^{T}-\alpha \Delta L e_{y} e_{y}^{T}\right)
$$

と選ぶ. $\Delta M, G$ も同様の考え方から

$$
\begin{aligned}
\dot{G} & =-\Gamma_{2}^{-1}\left(P \hat{\boldsymbol{x}} e_{y}^{T}+\beta G e_{y} e_{y}^{T}\right) \\
\Delta \dot{M} & =\Gamma_{3}^{-1}\left(B^{T} P \hat{\boldsymbol{x}} \boldsymbol{u}^{T}-\gamma \Delta M \boldsymbol{u} \boldsymbol{u}^{T}\right)
\end{aligned}
$$

と選ぶ. ここで $\Gamma_{1}>0, \Gamma_{2}>0, \Gamma_{3}>0, \alpha>0, \beta>0$, $\gamma>0$ とする. そこで (11) (13) 式を用いてそれぞれの $\operatorname{tr}\{\cdot\}$ の項を計算すると

$$
\begin{aligned}
\operatorname{tr}\left\{\Delta \dot{L}^{T} \Gamma_{1} \Delta L\right\}= & \hat{\boldsymbol{x}}^{T} P B \Delta L C \hat{\boldsymbol{x}} \\
& -\alpha e_{y} \Delta L^{T} \Delta L \boldsymbol{e}_{y} \\
\operatorname{tr}\left\{\Delta L^{T} \Gamma_{1} \Delta \dot{L}\right\}= & \hat{\boldsymbol{x}}^{T} C^{T} \Delta L^{T} B^{T} P \hat{\boldsymbol{x}} \\
& -\alpha e_{y} \Delta L^{T} \Delta L \boldsymbol{e}_{\boldsymbol{y}}
\end{aligned}
$$




$$
\begin{gathered}
\operatorname{tr}\left\{\dot{G}^{T} \Gamma_{2} G\right\}=-\hat{\boldsymbol{x}}^{T} P G \boldsymbol{e}_{y}-\beta \boldsymbol{e}_{y}^{T} G^{T} G \boldsymbol{e}_{y} \\
\operatorname{tr}\left\{G^{T} \Gamma_{2} \dot{G}\right\}=-\boldsymbol{e}_{y}^{T} G^{T} P \hat{\boldsymbol{x}}-\beta \boldsymbol{e}_{y}^{T} G^{T} G \boldsymbol{e}_{y} \\
\operatorname{tr}\left\{\Delta \dot{M}^{T} \Gamma_{3} \Delta M\right\}=\hat{\boldsymbol{x}}^{T} P B \Delta M \boldsymbol{u} \\
-\gamma \boldsymbol{u}^{T} \Delta M^{T} \Delta M \boldsymbol{u} \\
\operatorname{tr}\left\{\Delta M^{T} \Gamma_{3} \Delta \dot{M}\right\}=\boldsymbol{u}^{T} \Delta M^{T} B^{T} P \hat{\boldsymbol{x}} \\
-\gamma \boldsymbol{u}^{T} \Delta M^{T} \Delta M \boldsymbol{u}
\end{gathered}
$$

の関係式が成立するため，(4) 式，(5) 式の関係を代入すると (10) 式は

$$
\begin{aligned}
\dot{V}= & -\hat{\boldsymbol{x}}^{T}\left(Q+P B R^{-1} B^{T} P\right) \hat{\boldsymbol{x}}-2 \gamma \boldsymbol{u}^{T} \Delta M^{T} \Delta M u \\
& -\boldsymbol{e}_{y}^{T}\left(2 \alpha \Delta L^{T} \Delta L+2 \beta G^{T} G\right) \boldsymbol{e}_{y}
\end{aligned}
$$

となり, $\dot{V} \leq 0$ で $V$ は単調減少となる. $V$ が定常 $(\dot{V}=0)$ となるのは, $Q+P B R^{-1} B^{T} P>0$ であるので $\hat{\boldsymbol{x}} \rightarrow 0$ かつ $\boldsymbol{e}_{y}^{T}\left(\alpha \Delta L^{T} \Delta L+\beta G^{T} G\right) \boldsymbol{e}_{y} \rightarrow 0$ かつ $\boldsymbol{u}^{T} \Delta M^{T} \Delta M \boldsymbol{u} \rightarrow 0$ と なる場合である. $\left(\alpha \Delta L^{T} \Delta L+\beta G^{T} G\right)$ が正定, すなわち $\Delta L$ と $G$ がフルランク行列に収束するか, あるいは $\Delta L, G$ のど ちらか一方がフルランク行列に収束し， $\Delta M$ がフルランク行 列に収束するならば, $V$ が定常となるのは $\boldsymbol{e}_{y}=\boldsymbol{y}-C \hat{\boldsymbol{x}} \rightarrow 0$ かつ $\boldsymbol{u} \rightarrow 0$ のときである.このとき $\hat{\boldsymbol{x}} \rightarrow 0$ であるので, $\boldsymbol{y} \rightarrow 0$ であり, $(A+\Delta A, C)$ の可検出性の仮定から $\boldsymbol{x} \rightarrow 0$ となりシステムは漸近安定となる。

つぎに $\Delta L e_{y}=0, G e_{y}=0, \Delta M u=0$ の場合を考え る. $\hat{\boldsymbol{x}} \rightarrow 0$ となることから (8) 式より $(A-B \Delta L C-B K)$ は安定行列である。このとき $(6)$ 式は, $\boldsymbol{e}=\boldsymbol{x}-\hat{\boldsymbol{x}}$ を用いて,

$$
\begin{aligned}
\dot{\boldsymbol{x}}= & (A-B \Delta L C) \boldsymbol{x}-B K \hat{\boldsymbol{x}}-B \Delta M \boldsymbol{u} \\
= & (A-B \Delta L C)(\boldsymbol{e}+\hat{\boldsymbol{x}})-B K \hat{\boldsymbol{x}} \\
= & (A-B \Delta L C-B K) \hat{\boldsymbol{x}}+A \boldsymbol{e}-B \Delta L \boldsymbol{e}_{y} \\
= & (A-B \Delta L C-B K)(\boldsymbol{x}-\boldsymbol{e})+A \boldsymbol{e} \\
= & (A-B \Delta L C-B K) \boldsymbol{x} \\
& \quad-A \boldsymbol{e}+B \Delta L \boldsymbol{e}_{y}+B K \boldsymbol{e}+A \boldsymbol{e} \\
= & (A-B \Delta L C-B K) \boldsymbol{x}+B K \boldsymbol{e}
\end{aligned}
$$

また (6) 式から (8) 式を引くと誤差システムとして次式を 得る.

$$
\dot{e}=(A-B \Delta L C) e=A e-B \Delta L e_{y}=A e
$$
よって

$$
\left(\begin{array}{c}
\dot{x} \\
\dot{e}
\end{array}\right)=\left(\begin{array}{cc}
A-B \Delta L C-B K & B K \\
0 & A
\end{array}\right)\left(\begin{array}{l}
\boldsymbol{x} \\
\boldsymbol{e}
\end{array}\right)
$$

となり, $A-B \Delta L C-B K$ と $A$ が安定行列であることか ら, $x \rightarrow 0, e \rightarrow 0$ となり, この場合もシステムは漸近安定 となる。したがって, システムは漸近安定となる.

また (7) 式の両辺を時間微分すると, $L^{*}, M^{*}$ は時不变で あることからつぎの関係が成立する。

$$
\dot{L}=\Delta \dot{L}, \quad \dot{M}=\Delta \dot{M}
$$

以上のことをまとめると，(6) 式のシステムが安定となる ための (3) 式の制御則のゲイン $L, M$ および (8) 式のオブ
ザーバの行列 $\Delta L, \Delta M$ とオブザーバゲイン $G$ の決定方法 としてつぎの定理が成立する。

《定理 1》 (6) 式のシステムに対して, (3) 式のゲイン $L, M$ および (8) 式の行列 $\Delta L, \Delta M$ とオブザーバゲイン $G$ を

$$
\begin{aligned}
\dot{L} & =\Delta \dot{L}=\Gamma_{1}^{-1}\left(B^{T} P \hat{x}(C \hat{\boldsymbol{x}})^{T}-\alpha \Delta L e_{y} e_{y}^{T}\right) \\
\dot{G} & =-\Gamma_{2}^{-1}\left(P \hat{\boldsymbol{x}} e_{y}^{T}+\beta G e_{y} e_{y}^{T}\right) \\
\dot{M} & =\Delta \dot{M}=\Gamma_{3}^{-1}\left(B^{T} P \hat{x} u^{T}-\gamma \Delta M u u^{T}\right)
\end{aligned}
$$

と選んだときシステムは漸近安定となる。ただし $\Gamma_{1}>0$, $\Gamma_{2}>0, \Gamma_{3}>0, \alpha>0, \beta>0, \gamma>0$ とする.

$L, \Delta L, M, \Delta M, G$ は初期值 $L(0), \Delta L(0), M(0)$, $\Delta M(0), G(0)$ を適当に与えることにより，(25)〜(27) 式 から $\hat{x}, C \hat{\boldsymbol{x}}, e_{y}, u$ の情報を用いることによってオンライ ンで求めることができる.

[注 1] $\Delta L, \Delta M$ したがって $L, M$ を(25) 式, (27) 式で 求めるのは閉ループシステムを安定にするためであって, $L^{*}$, $M^{*}$ の推定值を求めるわけではない.

[注 2] $G(0)$ は任意の初期值を与えることにより求められ るが, 本論では一つの選び方の指標としてつぎのノミナルシ ステムに対するオブザーバゲインを用いることとする.

$$
\begin{aligned}
& G(0)=S C^{T} R_{o}^{-1} \\
& A S+S A^{T}-S C^{T} R_{o}^{-1} C S+B Q_{o} B^{T}=0
\end{aligned}
$$

ただし， $Q_{o}=Q_{o}^{T}>0, R_{o}=R_{o}^{T}>0$ である.

[注 3] (3) 式より具体的に $u$ を求める際, $(I+M)$ を正則 とし,

$$
\boldsymbol{u}=-(I+M)^{-1}(K \hat{\boldsymbol{x}}+L \boldsymbol{y})
$$

となり時変行列 $M$ に対する逆行列 $(I+M)^{-1}$ が含まれる が, $\Gamma_{3}$ の重みを十分大きくすることによって，行列 $M$ に対 する適応動作を小さくすることができるため, 適当な初期值 を与えることによって逆行列が存在する可能性を高めること ができる. $(I+M)$ が正則でなくなった場合には，本制御則 は可変行列の初期值に対する制約を課していないため, 適当 な行列 $M$ をその時点で再度与えることにより対処する.

駆動行列に不確かさが存在しない場合, 寸なわち $\Delta B=0$ の時は定理 1 で示した制御則は簡単になり，つぎの系を得る. [系1] (1) 式のシステムにおいて $\Delta B=0$ のとき，(3) 式 で $M=0$, (8) 式で $\Delta M=0$ とし, (3) 式の出力フィード バックゲイン $L$ および (8) 式の行列 $\Delta L$ とオブザーバゲイ ン $G$ を以下のように選んだときシステムは漸近安定となる.

$$
\begin{aligned}
& \dot{L}=\Delta \dot{L}=\Gamma_{1}^{-1}\left(B^{T} P \hat{x}(C \hat{\boldsymbol{x}})^{T}-\alpha \Delta L e_{y} e_{y}^{T}\right) \\
& \dot{G}=-\Gamma_{2}^{-1}\left(P \hat{\boldsymbol{x}} e_{y}^{T}+\beta G \boldsymbol{e}_{y} e_{y}^{T}\right)
\end{aligned}
$$

ここで $e_{y}=C \boldsymbol{x}-C \hat{\boldsymbol{x}}$ で, $\Gamma_{1}>0, \Gamma_{2}>0, \alpha>0, \beta>0$ とする。

\section{4. 数 值 例}

提案したシステム行列と駆動行列に不確かさを含む線形時 不変システムに対する可変ゲインコントローラの有効性を示 
すために，簡単な数値例を示す. 対象とするシステムはつぎ に示す定数行列をもつ時不変システムである.

$$
\begin{aligned}
& A=\left(\begin{array}{rrrr}
-3.000 & 1.000 & 0.000 & -0.030 \\
-0.990 & -1.210 & 0.034 & -0.111 \\
0.000 & 0.000 & 0.000 & 1.000 \\
0.900 & -1.550 & 0.000 & -1.890
\end{array}\right) \\
& B=\left(\begin{array}{r}
-0.32 \\
0.00 \\
0.00 \\
-1.60
\end{array}\right) \quad C=\left(\begin{array}{llll}
0.0 & 0.0 & 1.0 & 0.0 \\
0.0 & 0.0 & 0.0 & 1.0
\end{array}\right) \\
& L^{*}=(-1.00-0.20) \quad M^{*}=-0.30
\end{aligned}
$$

ここで行列 $A$ は安定行列である.このとき, $A+\Delta A$ の固 有值の実部の最大値は 0.758 となり, 不確かさによりシステ ムが不安定になる場合の例である。 そこで, (5) 式の解 $P$ と (4) 式の $K$ を求めると以下のようになる.

$$
\begin{aligned}
P & =\left(\begin{array}{rrrr}
0.059 & -0.087 & 0.197 & 0.128 \\
-0.087 & 0.130 & -0.297 & -0.195 \\
0.197 & -0.297 & 1.806 & 0.579 \\
0.128 & -0.195 & 0.579 & 0.436
\end{array}\right) \\
K & =\left(\begin{array}{llll}
-0.224 & 0.340 & -0.990 & -0.739
\end{array}\right)
\end{aligned}
$$

ここで $Q=I, R=1.0$ とした.このとき， $(A+\Delta A-(B+$ $\Delta B) K)$ の固有値の実部の最大値は 0.197 である. そこで重 み行列を $\Gamma_{1}=I, \Gamma_{2}=I, \Gamma_{3}=1000 I, \alpha=1.0, \beta=1.0$, $\gamma=1.0$ とし, 初期値として

$$
\begin{aligned}
& L(0)=\left(\begin{array}{rr}
-1.0 & 1.0
\end{array}\right), \quad \Delta L(0)=\left(\begin{array}{ll}
1.0 & 1.0
\end{array}\right) \\
& M(0)=1.0, \quad \Delta M(0)=-1.0 \\
& G=\left(\begin{array}{rr}
-0.006 & 1.066 \\
0.006 & -0.667 \\
0.020 & -0.001 \\
-0.001 & 3.519
\end{array}\right)
\end{aligned}
$$

を取ったときの時間応答を示す. Fig. 1 はシステムの状態の 時間応答, Fig. 2 は入力の時間応答, Fig. 3 はオブザーバの 時間応答を示している.

ここで示した数値例は，オブザーバを併合した固定ゲイン コントローラだけでは安定化できない場合である。この例で は $A$ は安定行列であり, $A$ が安定でないときには Kuceraの 方法等を用いて安定化する必要があるが, 行列 $\mathrm{A}$ を安定行列 とすることができれば，ノミナルシステムに対するリカッチ 方程式を解き固定ゲイン $K$ を決定し，対象システムに含ま れる不確かさがマッチング条件と可検出性を满たしさえすれ ば，時変行列の初期值と重み行列を適当に設定することによ りロバスト安定を達成するコントローラを得ることができる ことを示している. シミュレーション結果からも, 提案した コントローラによりシステムの安定化が達成されていること がわかる. 提案したオブザーバにおいても，Fig. 1 と Fig. 3 をみると状態推定がしっかりと行なわれていることがわか

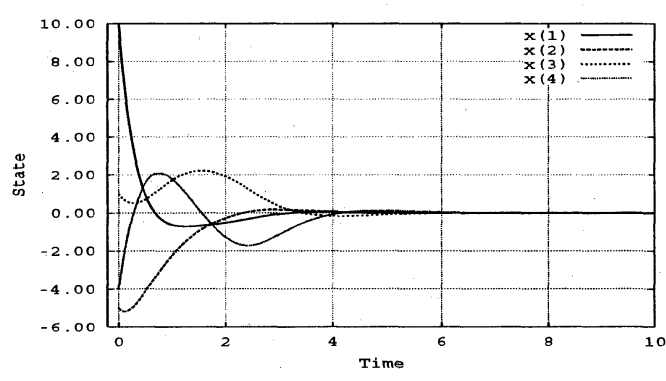

Fig. 1 Time Response of States

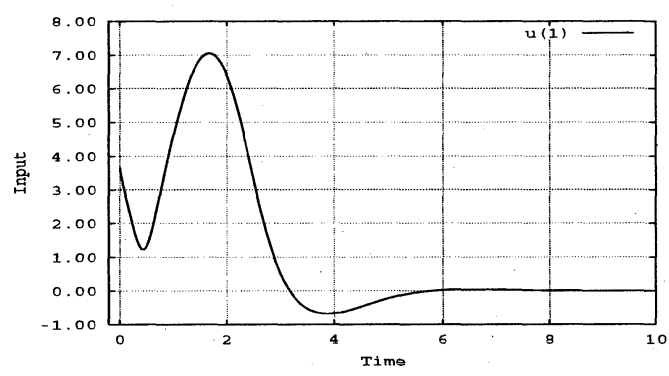

Fig. 2 Time Response of Input

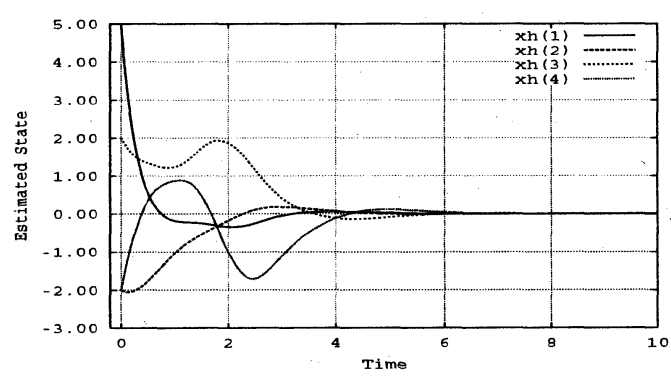

Fig. 3 Time Response of Estimated States

る. 各重み行列 $\Gamma_{1}, \Gamma_{2}, \Gamma_{3}, \alpha, \beta, \gamma$ は適応動作の大きさ を決定するものであるが， $\Gamma_{3}, \gamma$ 以外は適応動作の大きさ を小さくしすぎると, システムが収束するまでに長い時間を 要する可能性があるので, 適当な大きさに設定しなければな らない. また, 各時変行列の初期值については制的条件を与 えていないが, 初期值の与え方によってシステムのパフォー マンスに違いが出てくるため, 初期値に対しては検討する必 要がある. 駆動行列に不確かさが存在する場合には, 制御則 $に(I+M)^{-1}$ という逆行列が含まれ，その存在性を示す必 要があるが, 数值例で示しているように, 行列 $M$ の適応動 作の大きさを決定する $\Gamma_{3}$ の值を調整することにより，すな わち $\Gamma_{3}$ の值を十分大きくすることにより，行列 $M$ の動き を小さくすることができ，逆行列が存在するようにすること ができる.この例からもわかるように, 提案した設計法は不 確かさの上界に関する情報を必要とせずにロバスト安定を保 証するコントローラを簡単に設計でき, 不確かさの上界が未 知なシステムや上界が大きなシステムに対して有効である. 


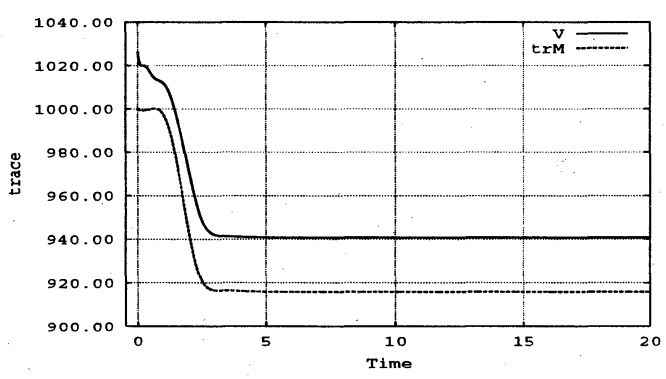

Fig. 4 Time Response of $V$ and $\operatorname{tr}\left\{\Delta M^{T} \Delta M\right\}$

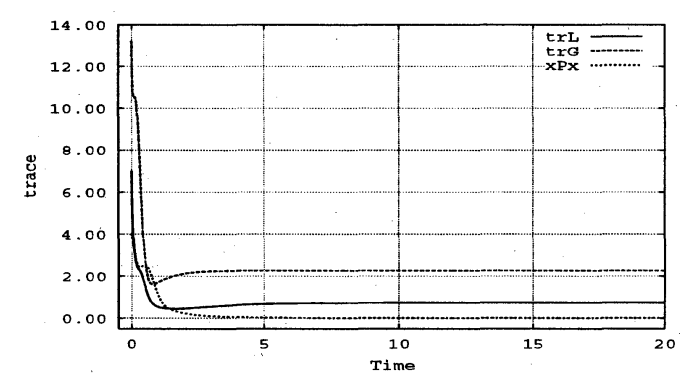

Fig. 5 Time Response of $\operatorname{tr}\left\{\Delta L^{T} \Delta L\right\}, \operatorname{tr}\left\{G^{T} G\right\}, x^{T} P x$

Fig. 4, Fig. 5 にリアプノフ関数 $V$ と各項の時間的変化を 示しておく。

つぎに [注 3] で述べている $I+M$ についてさらに一つ数 值例を示す．単位行列 $I$ が含まれているために, 時変行列の 適応動作の大きさに対する重み行列 $\Gamma_{3}$ の大きさを大きくし ておけば，[注 3] でも述べたように $(I+M)$ が正則行列とな る可能性が高いが，正則行列とならなかったときには制御則 が存在しなくなる，その解決策として行列が正則行列となら なくなった時点で新たな行列 $M$ を与えることを提案してい るが，ここではこの点について検証を行なう。ここで示す例 は，時刻 4 において行列 $M(4)$ の值を $2 * M(0)$ にしたとき の状態, 入力, オブザーバの時間応答である. 各行列等は以 下に示す通りである。

$$
\begin{aligned}
& A=\left(\begin{array}{rrrr}
-3.000 & 1.000 & 0.000 & -0.030 \\
-0.990 & 0.210 & 0.034 & -0.111 \\
0.000 & 0.000 & 0.000 & 1.000 \\
0.900 & -1.550 & 0.000 & -1.890
\end{array}\right) \\
& B=\left(\begin{array}{rr}
0.00 & -0.32 \\
0.00 & 0.00 \\
0.00 & 0.00 \\
-0.60 & 0.00
\end{array}\right) \quad C=\left(\begin{array}{llll}
0.0 & 0.0 & 1.0 & 0.0 \\
0.0 & 0.0 & 0.0 & 1.0
\end{array}\right) \\
& L^{*}=\left(\begin{array}{rr}
0.80 & -0.90 \\
0.00 & 0.40
\end{array}\right) \quad M^{*}=\left(\begin{array}{rr}
-0.30 & 0.00 \\
1.00 & 0.50
\end{array}\right)
\end{aligned}
$$

そこで重み行列を $\Gamma_{1}=0.1 I, \Gamma_{2}=0.5 I, \Gamma_{3}=500 I$, $\alpha=2.0, \beta=1.0, \gamma=1.0$ とし, 初期值としてを以下

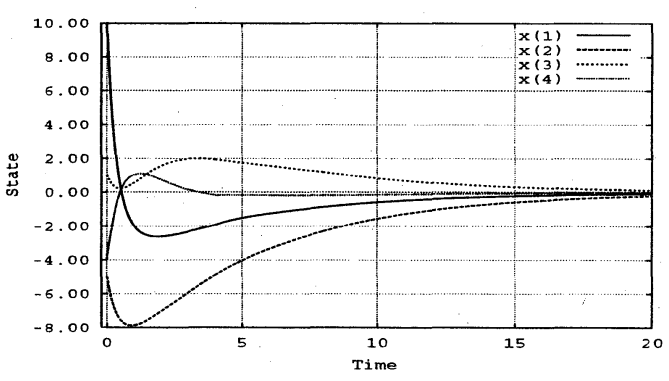

Fig. 6 Time Response of States

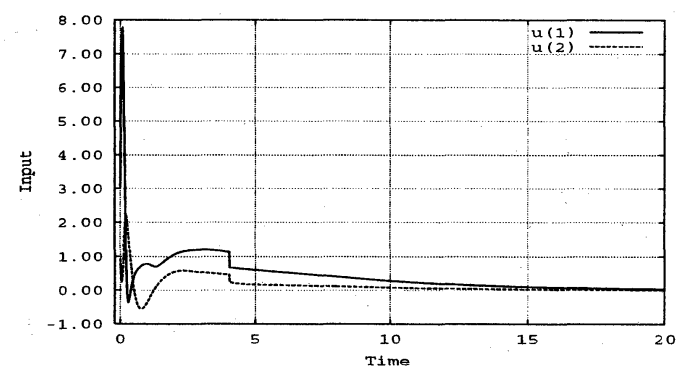

Fig. 7 Time Response of Input

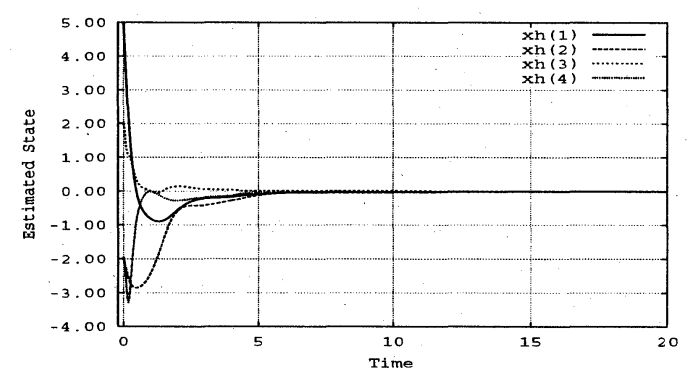

Fig. 8 Time Response of Estimated States

の値を取ったときの時間応答を示す.

$$
\begin{aligned}
& L(0)=\left(\begin{array}{rr}
-1.0 & 1.0 \\
0.0 & 1.0
\end{array}\right), \quad \Delta L(0)=\left(\begin{array}{ll}
1.0 & 1.0 \\
1.0 & 1.0
\end{array}\right) \\
& M(0)=\left(\begin{array}{ll}
2.4 & 0.0 \\
1.0 & 1.4
\end{array}\right), \quad \Delta M(0)=\left(\begin{array}{ll}
1.0 & 0.0 \\
0.0 & 1.0
\end{array}\right) \\
& G=\left(\begin{array}{rr}
-0.023 & 0.144 \\
0.083 & -0.112 \\
0.072 & 0.022 \\
0.022 & 0.799
\end{array}\right)
\end{aligned}
$$

Fig. 6 はシステムの状態の時間応答, Fig. 7 は入力の時間 応答, Fig. 8 はオブザーバの時間応答を示している.シミュ レーション結果から, $(I+M)$ の行列 $M(t)$ を途中で変更 しても時間応答では大きな変化はみられなかった．このこと は，行列 $(I+M(t))$ が正則でなくなった場合， $(I+M(t))$ が正則行列となるようにその時点で選び直しても安定性が保 た机ていることを示している. 行列 $M$ が時間的に変化する 


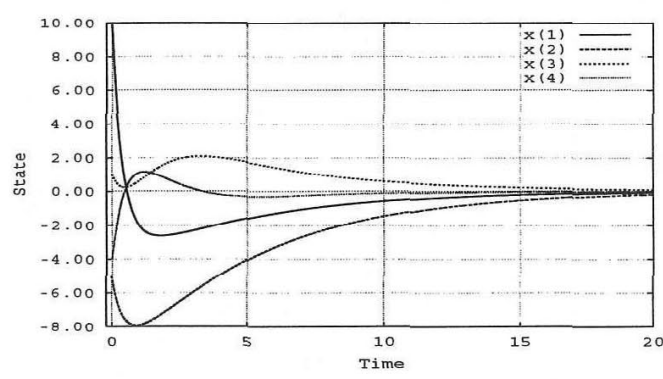

Fig. 9 Time Response of States

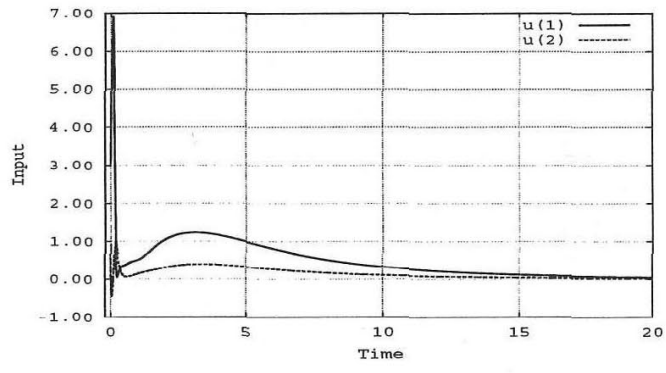

Fig. 10 Time Response of Input

場合 $(I+M)$ が常に正則であることを証明することは難し く，数値例においても $(I+M)$ が正則行列とならなくなる 例は稀でるため，ある時点で行列 $M$ の值を変化させた例を 示した.このような方法を取ることにより，(I+M)の問題 が厳密な意味において解決されたわけではないが，実用上は 問題がないと思われる。ここで Fig. 9, Fig. 10 に途中で行 列 $M(t)$ の值を変化させないときの状態と入力の時間応答を 示しておく.

\section{5. をと め}

本論文では, システム行列と駆動行列両方にマッチング条 件を满たす不確かさが存在する時不変線形システムに対する 適応ゲインコントローラの設計法を提案した。提案したコン トローラは，設計の過程において不確かさの上界に対する情 報を必要とせず，ノミナルシステムに対する LQ 制御則を得 るためのリカッチ方程式を解くたけで，安定性を保証するコ ントローラを得ることができる。提案した制御則は，システ 厶行列と駆動行列に存在する不確かさに対して，マッチング 条件と可検出性が成立する場合に適用可能であるが，対象と するシステムの出力值のみしか制御系設計で利用できないシ ステムに対しては, 従来の出力フィードバック制御系, オブ ザーバ併合型の制御系を設計する際の厳しい制約を必要とし ないため適用範囲が広くなる。特に，制御系を設計する際の パラメータ調整や繰り返し計算を必要としない点も大きな特 徵であり，不確かさの上界が未知な場合や非常に大きく，制 御系を設計するための設計パラメー夕調整が困難であるよう なシステムに対しては提案する制御則の有効性が大きくなる. しかしながら, 可変ゲイン行列の初期値によってシステムの
応答が変化するため, 今後の課題としてはシステムパフォー マンスを向上させる各可変行列の初期值の設定方法等の検討 が必要である。またシステム行列と駆動行列にマッチング条 件を满たさない非マッチング部分を含む場合に対する制御則 と安定化条件の導出については現在検討中である.

\section{参 考 文 献}

1）松岡，萩野：オブザーバを用いた適応ゲインコントローラに よる未知パラメー夕を含む線形システムに対するロバスト制 御，第 44 回自動制御連合講演会別刷，508/509 (2001)

2) I.R. Petersen: A Riccati Equation Approach to the Stabilization of Uncertain Linear Systems, Automatica, 22-4, $397 / 411$ (1986)

3) W.E. Schmitendorf: Designing Stabilizing Controllers for Uncertain Systems Using the Riccati Equation Approach, IEEE Trans. Automat. Contr., 33-4, 376/379 (1988)

4) F. Jabbari and W.E. Schmitendorf: A Noniterative Method for the Design of Linear Robust Controllers, IEEE Trans. Automat. Contr., 35-8, 954/957 (1990)

5) H. Kaufman, I Bar-Kana and K. Sobel: Direct Adaptive Control Algorithms: Theory and Applications, SpringerVerlag (1994)

6) Y.K. Choi, M.J. Chung and Z. Bien: An adaptive control scheme for robot manipulators, Int, J. Control, 44-4 1185/1191 (1986)

7) F. Jabbari and W.E. Schemitendorf: Robust Linear Controllers Using Observers, IEEE Trans. Automat. Contr., 36-12, 1509/1514 (1991)

8) F. Jabbari and W.E. Schmitendorf: Effects of Using Observers on Stabilization of Uncertain Linear Systems, IEEE Trans. Automat. Contr., 38-2, 266/271 (1993)

9) C.V. Hollot and A.R. Galimidi: Stabilizing Uncertain Systems: Recovering Full State Feedback Performance via an Observer, IEEE Trans. Automat. Contr., 31-11, 1050/1053 (1986)

10) A.R. Barmish and A.R. Galimidi: Robustness of Luenberger Observers: Linear Systems Stabilized via NonLinear Control, Automatica, 22-4, 413/423 (1986)

11) A.R. Galimidi and B.R. Barmish: The Constrained Lyapunov Problem and Its Application to Robust Output Feedback Stabilization, IEEE Trans. Automat. Contr., 31$5,410 / 419$ (1986)

12) W.E. Schmitendorf: Design of Observer-Based Robust Stabilizing Controllers, Automatica, 24-5, 693/696 (1988)

13) G. Gu: Stabilizability Conditions of Multivariable Uncertain Systems via Output Feedback Control, IEEE Trans. Automat. Contr., 35-8, 925/927 (1990)

14) V. Kucera and C.E. DE Souza: A Necessary and Sufficient Condition for Output Feedback Stabilizability, Automatica, 31-9, 1357/1359 (1995)

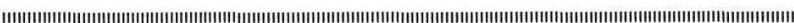

$$
\text { [著 者 紹 介] }
$$

\section{松 岡 正 喜（正会員）}

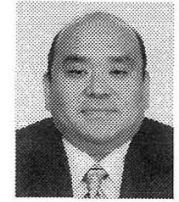

平成 5 年電気通信大学電気通信学部電子情報学 科卒. 平成 7 年同大大学院情報システム学研究科 博士前期課程了. 平成 13 年同大大学院電気通信 学研究科博士後期課程単位取得後退学. 現在湘南 工科大学助手. ロバスト制御, 分散制御, ファジ イ制御に従事. 電子情報通信学会, システム制御 情報学会, ファジィ学会, IEEE 会員. 
萩 野 剛二郎 (正会員)

昭 42 年東京大学工学部電子工学科卒. 昭 47 年 同大大学院博士課程了. 同年電気通信大学講師. 昭 51 年同大助教授。平成 2 年同大教授。システ 厶工学, 制御工学の研究に従事. 工学博士. 電子 情報通信学会, 電気学会会員. 